
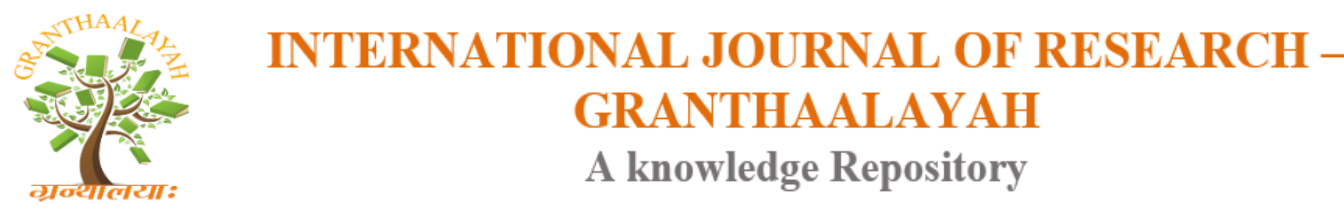

Science

\title{
HOLISTIC APPROACH UPON ORIGIN AND CURE OF DISEASES IN SUSHRUT SAMHITA
}

\author{
Dr. Nishi Arora ${ }^{1}$, Dr. Praveen Kumar ${ }^{2}$ \\ ${ }^{1}$ Associate Professor, A \& U Tibbia College, Karol Bagh, New Delhi, India \\ ${ }^{2}$ Professor, Ch. Brahm Prakash Ayurveda Charak Sansthan, New Delhi, India
}

\begin{abstract}
The definition of disease provided in the ancient Indian text Sushrut Samhita is found to be quite similar to the one provided in the contemporary times, both meaning dis-ease. Disease has been explained clearly and succinctly in this ancient text written by Aacharya Sushrut. Aacharya Sushrut is known as 'God of Surgery', not only in India but all throughout the world. Sushrut Samhita was chosen to illustrate the principle of Hoslistic approach to the origins and cures of diseases. The method selected was, explaining the relevant original verses in light of their most popular commentary 'Nirantarpad Vyakhya' by Aacharya Danhan. Aacharya Sushrut has defined 'disease' in the most simplified manner along with expressing a holistic approach to the origins and cures of these diseases. In this paper, this kind of holistic approach will be discussed in detail. Though the subject of origin of diseases and their cures is very wide, Aacharaya Sushrut has compiled the answers of such questions in a very concise and comprehensive manner.
\end{abstract}

Keywords: Vyadhi; Aadhyatmik; Aadhibhautik; Aadhidaivik.

Cite This Article: Dr. Nishi Arora, and Dr. Praveen Kumar. (2018). "HOLISTIC APPROACH UPON ORIGIN AND CURE OF DISEASES IN SUSHRUT SAMHITA.” International Journal of Research - Granthaalayah, 6(9), 49-52. https://doi.org/10.5281/zenodo.1435218.

\section{Introduction}

Sushrut Samhita is one of the most authentic texts of Ayurveda. It has described a lot about health and diseases. In the beginning, it says that Vyadhi/disease occurs when any kind of Dukh/pain is there. Just as 'Vyadhi' is associated with 'Dukh'; 'disease' is associated with 'dis-ease' meaning that any uneasiness due to some cause is known as a disease. In contemporary times the causes of diseases have been found to be innumerable, ranging from various infections caused by bacteria or viruses to endocrinal disbalances along with environmental pollutions and unhygienic conditions. Accordingly, the treatments are also available for these diseases. It is seen that with each passing day, more and more causes are being explored and cures are also being researched unendingly. 
Aacharya Sushrut, on the contrary, has defined 'disease' in the most simplified manner along with expressing a holistic approach to the origins and cures of these diseases. In this paper, this kind of holistic approach will be discussed in detail. The aim of the paper is to understand the concept of disease through a comprehensive and crispy description.

\section{Material and Methods}

Ayurveda is an ancient science of India. Aacharya Sushrut is known as the 'God of Surgery' throughout the world. Not only did he lay the foundations for surgery, he also made considerable contributions in the field of health and disease. Hence Sushrut Samhita was chosen to illustrate the principle of Hoslistic approach to the origins and cures of diseases. The method selected was to explain the relevant original verses in light of their most popular commentary 'Nirantarpad Vyakhya' by Aacharya Danhan.

\section{Discussion}

The text starts form the descent of Ayurveda to Earth and a little explanation of its science. The definition of 'disease' is given only after the introductory explanation. 'Taddukhsainyoga Vyadhayaha uchyate,1 which means that any kind of pain is called as a disease. The commentator has explained this with the word 'Tadd'. Aacharya Sushrut Samhita wanted to explain that it is about the 'Purush'2 (composed of Panchamahabhut \& Aatma). Further, it is told that Vyadhi means 'Giver of various kinds of pain'. These pains may be related to body's speech and mind ${ }^{3}$.

\section{Origin of Diseases}

These belong to three major classes which are further divided into seven types ${ }^{4}$. The major classes are:

1) Aadhyatmik- Here, Aatma word is used for body along with mind. The diseases occur in the body through Vaata, Pitta, and kapha (The three physical humours), and Rajas \& Tamas (The two components of mind among a total of three), which are known as 'Aadhyaatmik'.

- Aadi Bala Pravritta 5 - Diseases related to sperm and egg (genetic disorders).

- Janma Bala Pravritta ${ }^{5}$ - Diseases due to mother's ignorance/negligence during pregnancy. This can either be due to lack of nutrition or non-fulfilment of the desires of mother.

- Dosha Bala Pravritta ${ }^{5}$ Diseases due to faulty food habits and erratic lifestyles.

2) Aadhibhotik- The diseases that occur due to disbalances in the structural units of the body (Panchamahaabhuuta) are known as Aadibhotik.

- Sanghaat Bala Pravritta ${ }^{6}$ - Diseases due to external injuries or accidents.

3) Aadhidaivik- The diseases that occur due to the role of supernatural powers or power of the previous deeds are known as Aadhidaivik.

- Kaala Bala Pravritta - Diseases due to natural calamities or unbalanced seasonal changes.

- Daiva Bala Pravritta - Diseases related to supernatural powers or infections.

- Swabhava Bala Pravritta ${ }^{7}$ - Discomfort due to natural urges like hunger, thirst and the problems related to aging. 
All the above diseases may alternatively be understood ${ }^{8}$ in 4 ways. These are: 'Aagantavaha, Shaariraha, Maanasaha, Swabhaavakaashchayati'. With this verse, Aacharya Sushrut has explained that body and mind are the two seats of all diseases.

\section{Cure of Diseases}

The solution and cure to every disease has been condensed by Aachaarya Sushrut in mere half a line- 'Teshaam Sanshodhansanshamanaahaaraachaaraha Samyak Prayukta Nigrahahetawaha', which means that all of the diseases can be prevented and cured through appropriate use of the following four ways.

1) Sanshodhan (Purification) - It covers both external and internal purification.

2) Sanshaman (Pacification) - Pacification of Doshas, without expelling them out through the use of either internal or external medicine.

3) Aahara (Food) - Modification of food habits along with the focus on quality and amount of the food.

4) Aachara (Conduct) - Following the best of mannerism through mind and disciplined activities of daily living.

\section{Conclusion}

1) Though the subject of origin of diseases and what their cures are is very vast, Aacharaya Sushrut has compiled the answers of such questions in a very short and comprehensive manner.

2) Taking care of food habits and activities of daily living are the key factors in remaining in good health.

3) The body, mind and soul are inseparably interdependent on each other for both health and disease.

\section{References}

[1] Yadavji Trikamji (1994) Sushrut Samhita Niranatar Pad Vyakhya. Sushrut Sutra Sthan ch 1/22 page- 5.

[2] Yadavji Trikamji (1994) Sushrut Samhita Niranatar Pad Vyakhya. Sushrut Sutra Sthan ch 1/21 page- 5 .

[3] Yadavji Trikamji (1994) Sushrut Samhita Niranatar Pad Vyakhya. Sushrut Sutra Sthan ch 1/22 page- 5 .

[4] Yadavji Trikamji (1994) Sushrut Samhita Niranatar Pad Vyakhya. Sushrut Sutra Sthan ch 24/4 page- 97.

[5] Yadavji Trikamji (1994) Sushrut Samhita Niranatar Pad Vyakhya. Sushrut Sutra Sthan ch 24/5 page- 97.

[6] Yadavji Trikamji (1994) Sushrut Samhita Niranatar Pad Vyakhya. Sushrut Sutra Sthan ch 24/6 page- 97.

[7] Yadavji Trikamji (1994) Sushrut Samhita Niranatar Pad Vyakhya. Sushrut Sutra Sthan ch 24/7 page- 97.

[8] Yadavji Trikamji (1994) Sushrut Samhita Niranatar Pad Vyakhya. Sushrut Sutra Sthan ch 1/23 page- 5 . 
[9] Yadavji Trikamji (1994) Sushrut Samhita Niranatar Pad Vyakhya. Sushrut Sutra Sthan ch 1/26 page- 6 .

*Corresponding author.

E-mail address: nishiarora_doc@yahoo.co.in 